\title{
Intake of dietary folate and folic acid in Germany based on different scenarios for food fortification with folic acid
}

\author{
Yvonne Martiniak • Thorsten Heuer • \\ Ingrid Hoffmann
}

Received: 27 June 2014/Accepted: 6 October 2014/Published online: 24 October 2014

(C) The Author(s) 2014. This article is published with open access at Springerlink.com

\begin{abstract}
Purpose Besides the adverse health effects of a low folate intake, the risks of high intakes of folic acid have moved into the focus. The aim of this study was to investigate the potential range of folate and folic acid intake of the German population under consideration of different fortification scenarios.

Methods Food consumption data of 13,926 participants of the German National Nutrition Survey II (NVS II), collected with two 24-h recalls, were used to calculate the nutrient intake. The nutrient data are based on the German Nutrient Database (BLS), information from a market survey and analyses of multivitamin juices. The scenarios were modelled without, as well as with low and high fortification levels of folic acid.

Results The median intake of dietary folate equivalents ranged from $191 \mu \mathrm{g} / \mathrm{d}$ (men) and $168 \mu \mathrm{g} / \mathrm{d}$ (women) without fortification to $425 \mu \mathrm{g} / \mathrm{d}$ (men) and $334 \mu \mathrm{g} / \mathrm{d}$ (women) in the highest fortification scenario. Thus, 12.4-68.2\% (men) and 5.9-56.1\% (women) met the $300 \mu \mathrm{g} / \mathrm{d}$ recommended by the nutrition societies of Germany, Austria and Switzerland. In the highest fortification scenario, $1.9 \%$ (men) and $0.8 \%$ (women) exceeded the tolerable upper intake level (UL) of $1,000 \mu \mathrm{g} / \mathrm{d}$ folic acid given by the European Food Safety Authority. For supplement users, this proportion was 5.2 and $5.4 \%$.

Conclusions Only a high fortification of several foods leads to a marked increase of the proportion of population reaching the recommendation. Simultaneously, with a high
\end{abstract}

Y. Martiniak · T. Heuer $(\bowtie) \cdot$ I. Hoffmann Department of Nutritional Behaviour, Max Rubner-Institut, Federal Research Institute of Nutrition and Food, Haid-und-Neu-Str. 9, 76131 Karlsruhe, Germany e-mail: Thorsten.Heuer@mri.bund.de fortification a higher proportion exceeds the UL, especially in combination with supplements.

Keywords Dietary folate intake - Folic acid . Fortification · Supplementation · German National Nutrition Survey

\section{Introduction}

Many studies show the health benefits of natural food folate (reduced methyl and formyl folates) and of folic acid from supplements and fortified foods (pteroylmonoglutamic acid). An adequate folate intake during the periconception period helps to prevent congenital malformations (including neural tube defects) and pregnancy complications [1-3]. Low levels of folate can lead to homocysteine accumulation [4] and impairment of DNA repair mechanisms [5]. Epidemiological studies have suggested an association between high intake of folate and lower risk of cardiovascular disease, some cancers and agerelated cognitive decline [6-8]. However, the results of randomized controlled trials with folic acid did not support these findings in general [9-14].

In addition to the risks of a low folate intake, potential risks of high intakes of folic acid have moved into the focus of the discussion over the past years. New scientific evidence has emerged suggesting a possible link between high intake of folic acid and various types of cancer, particularly colorectal cancer [15-19]. Animal studies suggest that high folic acid intakes may have a dual effect: inhibiting the formation of neoplastic lesions in normal tissues and accelerating the malignant transformation of existing neoplasms [20]. Other postulated adverse effects of high folic acid intake include acceleration of cognitive decline during 
ageing (in combination with a vitamin B-12 deficiency) [21-23] and a reduction of the efficacy of antifolate drugs (used to treat cancer, epilepsy, rheumatic disease, psoriasis or malaria) [24-26]. A high intake of folic acid may result from supplements and/or from fortified foods.

To prevent neural tube defects, a mandatory fortification of flour with folic acid is practiced in over 50 countries, but has not been introduced in any European country [27]. In Germany, folic acid supplements are recommended during the periconceptional period [28] and folic acid is added to many foods, such as breakfast cereals, multivitamin juices (mixed fruit juice fortified with several vitamins) and other beverages, margarines, dairy products, sweets, convenience foods, and table salt. The amount of added folic acid varies widely between different products, brands, and storage time. Information on the consumption of fortified foods collected in nutrition surveys contains a degree of uncertainty, and actual folic acid contents in foods may differ from those presented in nutrient databases or on product labels.

Therefore, the objectives of this study were as follows:

1. to investigate the potential intake of dietary folate and folic acid of the German population based on the data of the German National Nutrition Survey II (NVS II) under consideration of different food fortification levels (no fortification with folic acid, low and high fortification level) and

2. to evaluate the percentage of the population meeting the recommended intake or exceeding the tolerable upper intake level (UL) of different food fortification levels.

The calculations were executed for the total population, for women of childbearing age (because of a more serious impact of a low intake) and for supplement users (because of a potentially higher risk of a too high intake of folic acid).

\section{Methods}

\section{Nutrition survey}

The intake of dietary folate and folic acid was calculated for 13,926 participants $(6,257$ men and 7,669 women) of the NVS II. The NVS II is a nationwide representative study conducted between November 2005 and January 2007 among German-speaking men and women between 14 and 80 years of age living in private households. The methods of the survey are described in detail elsewhere [29].

The nutrition data used for the present analysis were collected in two 24-h recalls. The participants were interviewed in detail about what they ate and drank on the day before, as well as about their supplement use during that day. The product names and quantity of the consumed supplements were recorded. For each participant, the interviews were carried out on 2 non-consecutive days with an average gap of about 16 days. The 24-h recalls were performed as computer-assisted telephone interviews using the programme EPIC-SOFT. This programme was developed within the study "European Prospective Investigation into Cancer and Nutrition" (EPIC) [30] and revised and adapted to the objectives of the NVS II [31]. The linkage of the consumed foods, beverages and supplements with a nutrient and a supplement database was conducted manually.

\section{Nutrient data}

The calculation of the nutrient intake was done based on the German Nutrient Database (BLS) version 3.01 [32]. Further information was supplemented from a market survey on fortified foods and the analyses of folic acid in different multivitamin juices (mixed fruit juice fortified with several vitamins) both conducted at the Max RubnerInstitut in 2010. The calculation of folic acid intake from supplements was based on an internal Max Rubner-Institut supplement database which contains product information of supplements, e.g. product names and nutrient contents from the package, producers or internet, from 2006 to 2010.

Heterogeneous definitions of the different terms for "folate" require a carful description especially for the purpose of the presented study. The term "natural food folates" comprises only naturally occurring folates in foods while "folic acid" is understood as the synthetic form (pteroylmonoglutamic acid) used only in supplements and in fortified foods. The generic term "folate" refers to all compounds of folate.

Dietary folate equivalents (DFE) were estimated, because the bioavailability of synthetic folic acid consumed in a meal is 1.7 times higher than the bioavailability of natural food folate [28]. On the European market, the fortification of food with folic acid is regulated on the basis of Regulation No. 1925/2006 of the European Parliament and of the Council (amended in Regulation No. 1170/2009) $[33,34]$. The declaration of folic acid on the label of fortified foods encompasses natural food folate plus added folic acid [34]. Therefore, the difference between the label value and the natural folate content (i.e. the folate content as given for a comparable non-fortified food by the BLS) was considered with a factor of 1.7. Afterwards, the amount of natural food folate was added again (label value $=$ natural food folate + folic acid; DFE $=$ natural food folate $+1.7 \times$ folic acid). 
Dietary reference values

The DFE intake was compared to the recommendation of $300-\mu \mathrm{g}$ DFE per day given in Germany, Austria and Switzerland [28] and in the Scandinavian countries [35] as well as to the lower recommendation of $200 \mu \mathrm{g} / \mathrm{d}$ given in Great Britain and the European Union [36, 37] and to the higher recommendation of $400 \mu \mathrm{g} / \mathrm{d}$ given in USA [38]. The intake of folic acid from fortified foods and supplements was compared to the UL of $1,000 \mu \mathrm{g} / \mathrm{d}$ by the European Food Safety Authority (EFSA) [39].

\section{Calculation of scenarios}

Because of limited accuracy of the consumption of fortified foods and the wide range of fortification levels, four scenarios with different levels of folic acid fortification were calculated to estimate potential intake levels. For the calculation of the scenarios, the added amount of folic acid to foods were varied for all foods that are potentially fortified with folic acid, independent of information about fortification or brand names which may have been recorded in the 24-h recalls.

The following 4 scenarios were calculated with different levels of fortification:

Scenario 1 (no fortification with folic acid) It was assumed that all participants consume no fortified foods, so that scenario 1 exclusively shows the intake of natural folate. All fortified foods which were named in the 24-h recalls were considered as non-fortified foods. In scenario 1a, the use of supplements was not considered, whereas in scenario $1 \mathrm{~b}$ folic acid intake from supplements named in the 24-h recalls was considered.

Scenario 2 and 3 (low and high fortification with folic acid of certain food groups) It was assumed that all participants consuming lemonades (soda), breakfast cereals, margarines, packet soups, cocoa powder and cocoa drinks, certain dairy products and certain sweets had consumed these foods with the lowest (scenario 2) or highest (scenario 3) fortification level among these food groups observed during a market survey (Table 1), regardless of whether the participants had declared the food item as "fortified", "not fortified" or "fortification unknown" during the interview. The fortification level of multivitamin juices (mixed fruit juice fortified with several vitamins) was based on the analyses of the Max Rubner-Institut [40]. Scenario 3 included the maximum folic acid content directly after production and scenario 2 the minimum content after storage of 12 months (Table 1). The fortification level of other multivitamin and mixed fruit beverages diluted with water was calculated with a proportion of $50 \%$ multivitamin juice.
Table 1 Amount of added folic acid which is used in the scenarios 2,3 and 4

\begin{tabular}{|c|c|c|c|}
\hline Food group & $\begin{array}{l}\text { Scenario } 2 \\
(\mu \mathrm{g} / 100 \mathrm{~g})\end{array}$ & $\begin{array}{l}\text { Scenario } 3 \\
(\mu \mathrm{g} / 100 \mathrm{~g})\end{array}$ & $\begin{array}{l}\text { Scenario } 4 \\
(\mu \mathrm{g} / 100 \mathrm{~g})\end{array}$ \\
\hline $\begin{array}{l}\text { Multivitamin/mixed fruit } \\
\text { juices }^{\text {a }}\end{array}$ & 71 & 245 & 245 \\
\hline $\begin{array}{l}\text { Multivitamin/mixed fruit } \\
\text { beverages (water diluted) }\end{array}$ & 36 & 123 & 123 \\
\hline Lemonade (soda) & 30 & 30 & 30 \\
\hline Breakfast cereals & 93 & 340 & 340 \\
\hline Muesli & 6 & 76 & 76 \\
\hline Cereal bar & 68 & 168 & 168 \\
\hline Cocoa powder & 194 & 286 & 286 \\
\hline $\begin{array}{l}\text { Milk (with fruit preparation/ } \\
\text { flavour) }\end{array}$ & 9 & 25 & 25 \\
\hline $\begin{array}{l}\text { Buttermilk (with fruit } \\
\text { preparation/flavour) }\end{array}$ & 30 & 30 & 30 \\
\hline $\begin{array}{l}\text { Whey (with fruit preparation/ } \\
\text { flavour) }\end{array}$ & 26 & 43 & 43 \\
\hline $\begin{array}{l}\text { Yoghurt drink (with fruit } \\
\text { preparation/flavour) }\end{array}$ & 82 & 82 & 82 \\
\hline Margarine & 100 & 1,000 & 1,000 \\
\hline Packet soup & 18 & 25 & 25 \\
\hline Candies & 300 & 800 & 800 \\
\hline Ice cream (sorbet) & 47 & 47 & 47 \\
\hline Gummy candies & 100 & 400 & 400 \\
\hline Dextrose & 200 & 400 & 400 \\
\hline Diet drink & 13 & 26 & 26 \\
\hline Diet powder & 108 & 487 & 487 \\
\hline Protein powder & 108 & 239 & 239 \\
\hline Energy powder & 360 & 600 & 600 \\
\hline Protein drink & 33 & 33 & 33 \\
\hline Table salt & 0 & 0 & 10,000 \\
\hline
\end{tabular}

Scenario 4 (high fortification with folic acid for certain food groups plus table salt fortified with folic acid) Scenario 4 is based on scenario 3. In addition, table salt used in the household was subjected to fortification with folic acid. Depending on the salt content (BLS) of the declared food items, a respective amount of folic acid (100 $\mu \mathrm{g}$ folic acid per gram salt) was calculated and added to all salted food items declared as homemade (preparation type: "homemade" in EPIC-SOFT).

Statistical analysis

The DFE intake of a person was calculated as the mean of the two 24-h recalls each participant completed. Based on these data, the DFE intakes as well as the intakes of folic 
acid in the different groups are presented as median, $95 \%$ confidence interval of median and 95th percentile. Differences in the frequency distribution of folic acid supplement use between men and women as well as age classes were tested by the chi-square test. The Jonckheere-Terpstra test was used to assess trends across age classes for supplement use. The nutrient intake data were weighted with regard to the data of the German official statistics (microcensus 2006, Federal Statistical Office) for sex, age, region, education, employment and household size. All statistical analyses were performed with SAS (version 9.2, SAS Institute Inc., Cary, North Carolina, USA). Boxplots were generated with SPSS (version 20.0, IBM Corporation, Armonk, New York, USA).

\section{Results}

Total population

The median daily intake of DFE (excluding supplements) ranged from $191 \mu \mathrm{g}$ (scenario 1) to $425 \mu \mathrm{g}$ (scenario 4) for men and from 168 to $334 \mu$ g for women (Fig. 1; Table 2). Without folic acid fortification (scenario 1 ), $12.4 \%$ of the men and $5.9 \%$ of the women met the recommended daily intake of $300-\mu \mathrm{g}$ DFE of the German-speaking countries and the Scandinavian countries $[28,35]$. In the scenario with the highest folic acid fortification level (scenario 4), $68.2 \%$ of the men and $56.1 \%$ of the women met this recommendation. The median intake for women also did not meet the lower Great Britain- and pan-Europeanrecommendation of $200 \mu \mathrm{g} / \mathrm{d}[36,37]$ with natural food folate in scenario 1 , whereas men almost reached the recommendation of $200 \mu \mathrm{g} / \mathrm{d}$. With high fortification (scenario 4$), 86.0 \%$ of the men and $73.3 \%$ of the women met the recommended level of $200 \mu \mathrm{g} / \mathrm{d}$. The higher recommendation of $400 \mu \mathrm{g} / \mathrm{d}$ in the USA [38] can hardly be reached without fortification. At the same time in the scenario with the highest fortification level (scenario 4), $1.9 \%$ of the men and $0.8 \%$ of the women exceeded the UL of 1,000 $\mu \mathrm{g}$ folic acid per day [39] (Table 2). In scenario 4 , the 95th percentile of folic acid intake from fortified foods was $695 \mu \mathrm{g} / \mathrm{d}$ for men and $467 \mu \mathrm{g} / \mathrm{d}$ for women (Table 2).

Women of childbearing age (15-45 years)

For women of childbearing age the median daily intake of DFE (excluding supplements) ranged from $159 \mu \mathrm{g}$ (scenario 1a) to $348 \mu \mathrm{g}$ (scenario 4) (Table 2). Without fortification with folic acid (scenario 1a), $4.8 \%$ of the women between 15 and 45 years met the recommended daily intake of 300- $\mu$ g DFE [28]. This proportion increased to

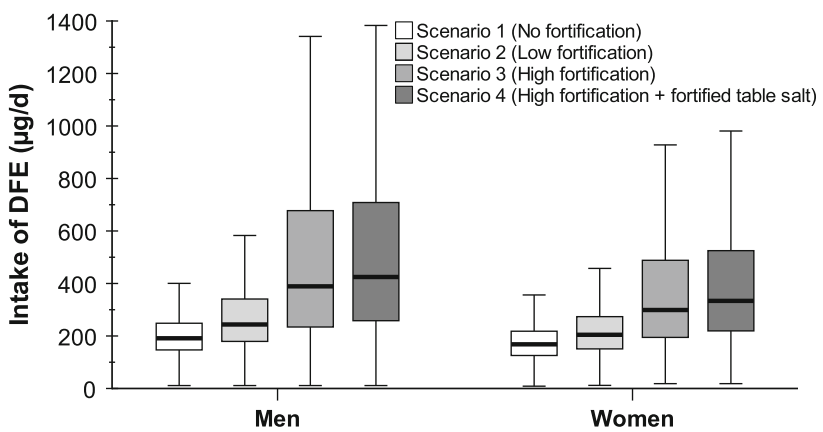

Fig. 1 Intake of dietary folate equivalents (DFE) in the German population ( $n=13,926)$ by gender for different fortification scenarios (excluding supplements). Boxplots show median, upper and lower quartiles and minimum and maximum data values excluding extreme values and outliers

$11.1 \%$ when considering the use of supplements (scenario 1b). Without supplements and with a low fortification level (scenario 2), the percentage of women of childbearing age achieving the recommended intake of 300- $\mu \mathrm{g}$ DFE per day was higher $(22 \%)$, while no woman showed an intake of folic acid exceeding the UL. Under the assumption of a high fortification level (scenario 4), about $50 \%$ met the recommended intake level and $1.3 \%$ of the women of childbearing age exceeded the UL (Table 2).

In Germany, women of childbearing age are recommended to supplement $400 \mu \mathrm{g}$ of folic acid per day in order to reduce their risk of a pregnancy affected by spina bifida or other neural tube defects. In this study, about $8 \%$ of the women of childbearing age took supplements containing folic acid, but only $2 \%$ at doses of at least $400 \mu \mathrm{g} / \mathrm{d}$.

\section{Users of supplements containing folic acid}

In Germany, more women $(10 \%)$ than men $(7 \%)$ used supplements containing folic acid $(P<0.001)$. The proportion of supplement users differed between age classes $(P<0.001$, resp. for men and women $)$ and increased across the age classes $(P<0.001$, resp. for men and women) (Table 3).

In the group of folic acid supplement users, the median daily intake of natural food folate was $207 \mu \mathrm{g}$ for men and $187 \mu \mathrm{g}$ for women (scenario 1a). Thus, the supplement users have a higher intake of natural food folate compared to the total population (Table 2). The median daily DFE intake including supplements ranged from $488 \mu \mathrm{g}$ (scenario $1 \mathrm{~b}$ ) to $786 \mu \mathrm{g}$ (scenario 4) for men and from $500 \mu \mathrm{g}$ (scenario $1 b$ ) to $697 \mu \mathrm{g}$ (scenario 4) for women (Table 2). Just with supplements (not considering fortified foods), the recommended daily intake of $300 \mu \mathrm{g}$ [28] was achieved by $91.2 \%$ of the men and $87.4 \%$ of the women within this group. The median intake of supplemented folic acid was 
Table 2 Intake of DFE and folic acid as well as the percentage of the German population meeting the recommended intake (200- $\mu \mathrm{g}, 300-\mu \mathrm{g}$ and $400-\mu \mathrm{g}$ DFE per day) and the percentage of the German population exceeding the UL (1,000 $\mu \mathrm{g}$ folic acid per day)

\begin{tabular}{|c|c|c|c|c|c|c|c|c|}
\hline \multirow[t]{2}{*}{ Scenarios } & \multicolumn{5}{|l|}{$\mathrm{DFE}^{\mathrm{a}}$} & \multicolumn{3}{|l|}{ Folic acid } \\
\hline & $\begin{array}{l}\text { Median }(95 \% \text { CI }) \\
(\mu \mathrm{g} / \mathrm{d})\end{array}$ & $\begin{array}{l}\mathrm{P}^{\mathrm{b}} 5^{\mathrm{b}} \\
(\mu \mathrm{g} / \mathrm{d})\end{array}$ & $\begin{array}{l}\geq 200 \\
\mu \mathrm{g} / \mathrm{d}^{\mathrm{b}}(\%)\end{array}$ & $\begin{array}{l}\geq 300 \\
\mu \mathrm{g} / \mathrm{d}^{\mathrm{b}}(\%)\end{array}$ & $\begin{array}{l}\geq 400 \\
\mu \mathrm{g} / \mathrm{d}^{\mathrm{b}}(\%)\end{array}$ & $\begin{array}{l}\text { Median }(95 \% \text { CI }) \\
(\mu \mathrm{g} / \mathrm{d})\end{array}$ & $\begin{array}{l}\mathrm{P}^{\mathrm{b}} 5^{\mathrm{b}} \\
(\mu \mathrm{g} / \mathrm{d})\end{array}$ & $\begin{array}{l}>1,000 \\
\mu \mathrm{g} / \mathrm{d}^{\mathrm{b}}(\%)\end{array}$ \\
\hline \multicolumn{9}{|l|}{ Total population, men $(n=6,257)^{\mathrm{c}}$} \\
\hline 1. No fortification & $191(189,193)$ & 366 & 45.7 & 12.4 & 3.1 & $0(0,0)$ & 0 & 0.0 \\
\hline 2. Low fortification ${ }^{\mathrm{d}}$ & $244(241,247)$ & 608 & 67.2 & 33.3 & 16.2 & $17(16,18)$ & 224 & 0.0 \\
\hline 3. High fortification ${ }^{\mathrm{d}}$ & $389(380,400)$ & 1,382 & 81.7 & 62.8 & 48.9 & $100(95,105)$ & 674 & 1.8 \\
\hline $\begin{array}{l}\text { 4. High fortification }{ }^{\mathrm{d}}+\text { fortified table } \\
\text { salt }\end{array}$ & $425(414,434)$ & 1,419 & 86.0 & 68.2 & 53.0 & $123(116,128)$ & 695 & 1.9 \\
\hline \multicolumn{9}{|l|}{ Total population, women $(n=7,669)^{\mathrm{c}}$} \\
\hline 1. No fortification & $168(166,170)$ & 310 & 32.8 & 5.9 & 1.3 & $0(0,0)$ & 0 & 0.0 \\
\hline 2. Low fortification ${ }^{\mathrm{d}}$ & $205(202,207)$ & 460 & 51.9 & 19.2 & 7.7 & $10(9,11)$ & 142 & 0.0 \\
\hline 3. High fortification ${ }^{\mathrm{d}}$ & $299(292,306)$ & 962 & 73.9 & 49.8 & 34.3 & $66(63,70)$ & 446 & 0.8 \\
\hline $\begin{array}{l}\text { 4. High fortification } \\
\text { salt }\end{array}$ & $334(326,341)$ & 997 & 79.3 & 56.1 & 39.0 & $86(82,90)$ & 467 & 0.8 \\
\hline \multicolumn{9}{|l|}{ Women of childbearing age $(n=3,720)$} \\
\hline 1. (a) No fortification & $159(156,164)$ & 299 & 28.9 & 4.8 & 0.9 & $0(0,0)$ & 0 & 0.0 \\
\hline 1. (b) No fortification + supplements & $165(160,171)$ & 462 & 33.6 & 11.1 & 6.0 & $0(0,0)$ & 100 & 0.4 \\
\hline 2. Low fortification ${ }^{\mathrm{d}}$ & $207(200,213)$ & 512 & 52.6 & 22.0 & 9.8 & $15(13,18)$ & 182 & 0.0 \\
\hline 3. High fortification ${ }^{\mathrm{d}}$ & $311(296,333)$ & 1,106 & 74.6 & 52.9 & 36.8 & $78(68,87)$ & 525 & 1.3 \\
\hline $\begin{array}{l}\text { 4. High fortification }{ }^{\mathrm{d}}+\text { fortified table }_{\text {salt }}\end{array}$ & $348(332,363)$ & 1,142 & 80.0 & 58.6 & 41.8 & $100(91,109)$ & 541 & 1.3 \\
\hline \multicolumn{9}{|l|}{ Folic acid supplement users, men $(n=442)$} \\
\hline 1. (a) No fortification & $207(200,211)$ & 363 & 52.3 & 14.3 & 3.6 & $0(0,0)$ & 0 & 0.0 \\
\hline 1. (b) No fortification + supplements & $488(480,500)$ & 1,154 & 99.3 & 91.2 & 68.8 & $150(150,200)$ & 500 & 1.6 \\
\hline 2. Low fortification ${ }^{\mathrm{d}}+$ supplements & $554(540,565)$ & 1,303 & 99.6 & 95.0 & 79.0 & $202(200,208)$ & 627 & 1.6 \\
\hline 3. High fortification ${ }^{\mathrm{d}}+$ supplements & $749(722,773)$ & 1,948 & 99.8 & 97.3 & 89.1 & $314(300,325)$ & 962 & 4.8 \\
\hline $\begin{array}{l}\text { 4. High fortification }{ }^{\mathrm{d}}+\text { fortified table } \\
\text { salt }+ \text { supplements }^{\text {s. }}\end{array}$ & $786(746,812)$ & 2,006 & 99.8 & 98.2 & 91.4 & $332(320,351)$ & 1,022 & 5.2 \\
\hline \multicolumn{9}{|c|}{ Folic acid supplement users, women $(n=745)$} \\
\hline 1. (a) No fortification & $187(177,195)$ & 336 & 42.6 & 8.7 & 2.3 & $0(0,0)$ & 0 & 0.0 \\
\hline 1. (b) No fortification + supplements & $500(472,527)$ & 1,266 & 98.5 & 87.4 & 65.8 & $200(200,200)$ & 600 & 2.7 \\
\hline 2. Low fortification ${ }^{\mathrm{d}}+$ supplements & $545(511,577)$ & 1,323 & 99.1 & 93.0 & 73.4 & $204(200,215)$ & 625 & 2.7 \\
\hline 3. High fortification ${ }^{\mathrm{d}}+$ supplements & $663(627,714)$ & 1,914 & 99.2 & 95.4 & 83.9 & $283(257,300)$ & 1,000 & 5.0 \\
\hline $\begin{array}{l}\text { 4. High fortification }{ }^{\mathrm{d}}+\text { fortified table }^{\text {salt }+ \text { supplements }^{-}}\end{array}$ & $697(658,738)$ & 1,933 & 99.2 & 96.1 & 87.7 & $299(275,322)$ & 1,020 & 5.4 \\
\hline
\end{tabular}

DFE dietary folate equivalents, $U L$ tolerable upper intake level, $C I$ confidence interval, $P 95$ 95th percentile

a To calculate DFE, synthetic folic acid has been considered with a factor of 1.7

${ }^{\mathrm{b}}$ Data represents short-term consumption and therefore the proportions of adults with DFE/folic acid intake above the recommended intakes and the UL may be an overestimation

${ }^{c}$ Supplement use not considered

${ }^{\mathrm{d}}$ Foods considered for fortification: multivitamin juices, mixed fruit beverages, lemonades (soda), breakfast cereals, margarines, packet soups, cocoa powder and cocoa drinks, certain dairy products, and certain sweets

$150 \mu \mathrm{g} / \mathrm{d}$ for men and $200 \mu \mathrm{g} / \mathrm{d}$ for women, whereas the 95th percentile was $500 \mu \mathrm{g} / \mathrm{d}$ for men and $600 \mu \mathrm{g} / \mathrm{d}$ for women. In the scenario with the highest fortification level (scenario 4 ), $98.2 \%$ of the men and $96.1 \%$ of the women achieved the recommended $300 \mu \mathrm{g} / \mathrm{d}$. At the same time, $5.2 \%$ of the men and $5.4 \%$ of the women exceeded the $\mathrm{UL}$ of $1,000-\mu \mathrm{g}$ folic acid per day (Table 2).

\section{Discussion}

The present study describes several scenarios of folic acid fortification based on the representative data of the NVS II. The results show a low intake of natural food folate (scenario 1) in Germany with respect to the recommended 300- $\mu \mathrm{g}$ DFE per day [28]. Without fortification, only 
Table 3 Use of supplements containing folic acid (\%) by age classes

\begin{tabular}{llll}
\hline & $\begin{array}{l}\text { Men } \\
(n=6,257)\end{array}$ & $\begin{array}{l}\text { Women } \\
(n=7,669)\end{array}$ & $P$ value* \\
\hline Age**, $y$ & & & $<0.001$ \\
$14-18$ & 2.7 & 3.3 & \\
$19-24$ & 5.0 & 8.2 & \\
$25-34$ & 6.4 & 10.4 & \\
$35-50$ & 7.6 & 8.6 & \\
$51-64$ & 7.5 & 11.5 & $<0.001$ \\
$65-80$ & 9.1 & 11.9 & \\
All & 7.1 & 9.8 & \\
\hline
\end{tabular}

* Significance of differences between men and women assessed by chi-square test

** Trends across age classes assessed by Jonckheere-Terpstra test were significant, $P$ for trend $<0.001$

$12.4 \%$ (men) and $5.9 \%$ (women) met this recommendation. A low folate intake has also been shown in previous studies in Germany [41, 42] and for most countries in Europe [43-45]. In Germany, major food sources for DFE are bread, vegetables, fruits, beverages as well as milk and dairy products [46].

In 2013, the nutrition societies of Germany, Austria and Switzerland lowered the recommendation for folate from 400 to $300 \mu \mathrm{g}$ DFE per day for adolescents and adults (nonpregnant women) [28], now corresponding with the recommendation in the Scandinavian countries [35]. Even lower amounts $(200 \mu \mathrm{g} / \mathrm{d})$ are recommended in Great Britain and by the European Commission [36, 37], while in the USA the recommendation of the Institute of Medicine lies highest with $400 \mu \mathrm{g} / \mathrm{d}$ [38]. The current German recommendation of 300- $\mu$ g DFE per day includes a safety margin and not meeting this intake level can therefore not be judged as an inadequate folate intake [28]. Taking this into account, different cut-off points based on different international recommendations are presented in this work. With respect to the lowest recommended intake of $200 \mu \mathrm{g} / \mathrm{d}$ (Great Britain and European Union) [36, 37], the folate intake in Germany is less critical.

The intake of DFE among German adolescents and adults can be increased by the consumption of fortified foods or of large amounts of one fortified food item (e.g. multivitamin juices).

Different fortification scenarios (partly in combination with supplements) reveal a wide range of potential folic acid intake levels. The consumption of foods with a low fortification level does not lead to a substantial increase of the proportion of the population meeting the recommendation of the German-speaking countries. However, with a high fortification level, almost $70 \%$ of the men and about $55 \%$ of the women met the recommended $300 \mu \mathrm{g} / \mathrm{d}$, whereas about $80 \%$ met the level of $200 \mu \mathrm{g} / \mathrm{d}$. But this also results in a higher proportion of persons exceeding the UL ( $1.9 \%$ of the men and $0.8 \%$ of the women). The UL is an estimation of the maximum level of chronic daily intake, which carries no considerable risk of adverse health effects, whereas occasionally exceeding the UL does not seem to be a severe health threat [39].

The Scientific Committee on Food and the EFSA have set the UL for folic acid at 1,000 $\mu \mathrm{g} / \mathrm{d}$ [39] because higher doses of folic acid could delay the diagnosis of vitamin B-12 deficiency by masking the anaemia of vitamin B-12 deficiency, which can lead to irreversible neurological damage. With respect to a potential tumour progression, the current UL of 1,000- $\mu$ g folic acid per day may be too high, but the EFSA Scientific Cooperation Working Group concluded that there is no sufficient data to allow a full quantitative risk assessment of folic acid and cancer [27]. The possible harm of high folic acid intake depends most likely on additional factors such as age, individual supply status (e.g. vitamin B-12 status) and genetic polymorphisms $[15,21,47-50]$. With a lower UL, the percentage of persons exceeding the UL would be higher than presented in this study.

Particularly for women of childbearing age, a deficient intake can have serious consequences (neural tube defects or other prenatal malformations) but the intake of natural food folate within this group was even lower than within the total group of women. Without fortification with folic acid, only $4.8 \%$ of the women between 15 and 45 years met the recommended daily intake of $300 \mu \mathrm{g}$ DFE (scenario 1a). With a high fortification level of foods, $58.6 \%$ met this recommendation (scenario 4). In Germany, it is recommended that women of childbearing age take an additional amount of $400 \mu \mathrm{g}$ folic acid via supplements [28]. However, the proportion of woman meeting this recommendation was very low. This underlines that efforts have to be continued for more education about a diet rich in folate (such as green vegetables, fruits and wholegrainproducts), fortified foods and a well-timed use of folic acid supplements as important prevention measures to reduce the risk of a pregnancy affected by neural tube defects.

The proportion of adults with a folic acid intake above the UL increases if folic acid supplements are taken (about $5 \%$ among supplement users). The proportion of persons with folic acid supplement use is higher in the upper than in the lower age groups. A high intake of folic acid within the upper age groups may lead to critical situations due to a higher probability of occurrence of vitamin B-12 deficiency and/or undiagnosed preneoplastic lesions whose progression might be promoted by folic acid. Taking a closer look at the supplement users reveals a higher intake of natural food folate compared to the total population. These results suggest that particularly health-conscious 
people take folic acid supplements, who may not really need them, as well as elderly persons, who may have a higher health risk with high intakes of folic acid.

Because of the current fortification practice, i.e. products changing frequently and an amount of added folic acid that varies widely, the calculation of folic acid intake includes an uncertainty for scientific investigations and for consumers. Corresponding products from different brands are offered without fortification and with fortification at different levels. In addition, the exact content of folic acid in fortified foods is not known. In the European Union, the producers only have to declare the sum of natural folate and the added amount of folic acid on the label [34]. Furthermore, due to the instability of folic acid, variability in the declared content of $\pm 30 \%$ is accepted in Germany [51]. In some cases, including fruit juices, the tolerable deviation to the declared content may be more than $+50 \%$. In other countries, a wide variability regarding the declared value is also reported for beverages, bread and breakfast cereals with -64 to $+198 \%$ [52] and -2 to $+220 \%$ [53].

In the present calculation, the variability of the folic acid content in multivitamin drinks (mixed fruit juices fortified with several vitamins, $100 \%$ juice or water diluted) was considered (Table 1). Analyses of folic acid in nine multivitamin juices at the Max Rubner-Institut confirm the variability of the folic acid content depending on brand and storage time [40]. The consumption of several fortified foods or large amounts of one fortified food item (beverages especially can be consumed quickly in large amounts) may lead to a high intake of folic acid. At the individual level, the UL can easily be reached, e.g. by one glass of multivitamin juice $(250 \mathrm{~mL})$ plus $60 \mathrm{~g}$ breakfast cereal plus $250 \mathrm{~g}$ yoghurt drink (all with the highest fortification level of the corresponding food group). With multivitamin juice consumed right after production, the UL can be reached by consuming only $600 \mathrm{~mL}$ multivitamin juice. Considering the high contents of folic acid in freshly bottled multivitamin juices, the results support the discussion regarding the need for a restriction of folic acid fortification in selected foods such as beverages.

The estimates in the current study are subjected to several limitations. A limitation to dietary assessment methods is underreporting [54]. With the 24-h recalls used in NVS II, the energy intake is underestimated for $23 \%$ of the study participants. Underreporting was calculated by the quotient (=cut-off level) of energy intake and resting metabolic rate considering sex, age, body height and body weight [55-57]. An exclusion of these so-called underreporters and further of adolescents and of persons with incomplete data with respect to physical activity, body height and weight in further calculations of the Max
Rubner-Institut (data not shown) leads to a higher median DFE intake of $20 \mu \mathrm{g} / \mathrm{d}$ for the remaining group.

In general, data from 24-h recalls reflect short-term food consumption. A statistical method for estimating usual food consumption distribution was not applied to the calculations in this study. Methods such as the National Cancer Institute Method (NCI) [58] or the Multiple Source Method (MSM) [59] correct the within-person variation of short-term measured data to reach a narrower intake distribution. Even if an overestimation of the presented proportions of adults with DFE intake above the recommended intakes cannot be excluded, exceeding the UL remains a relevant subject.

Another limitation is that in the present study only the dietary intake of natural food folate and folic acid could be considered, but not the folate status (e.g. folate concentrations in red blood cells). The latter depends on multiple factors as intake of folate and other factors, e.g. interactions with other nutrients (e.g. vitamin C) and genetic polymorphisms [60] and may lead to partly different results.

The scenarios 2, 3 and 4 are based on the assumption that all participants consuming multivitamin juices, mixed fruit beverages, lemonades (soda), breakfast cereals, margarines, packet soups, cocoa powder and cocoa drinks, certain dairy products, and certain sweets do this exclusively in a fortified form. It is hypothesized that the intake of folic acid in these scenarios reaches the theoretically possible maximum. However, there are some fortified foods, which could not be considered in the analysis, e.g. ready-to-bake bread mixes and convenience products. The higher stability of folic acid compared with natural food folate during cooking could not be included in the BLS calculation algorithm (scenario 4). Furthermore, adding salt at the table could not be considered in scenario 4, but only $5.5 \%$ of the participants of the NVS II declared using table salt fortified with folic acid.

\section{Conclusion}

In order to meet the recommendation of Germany, Austria and Switzerland, a substantial increase of the intake of DFE is necessary. This may be reached by a higher consumption of foods fortified with high levels of folic acid. Consequently, women of childbearing age with a low intake of folate benefit from foods fortified with folic acid and/or the use of supplements containing folic acid, especially if they become pregnant. On the other hand, more people with a high consumption of fortified foods and even more in combination with supplement use can reach intake levels of folic acid above the UL. The challenge is to increase the dietary intake of natural food folate or folic 
acid for women of childbearing age and at the same time lowering (or not increasing) the proportion of adults exceeding the UL.

Acknowledgments The authors thank Bernd Hartmann (Max Rubner-Institut, Dept. Nutritional Behaviour) for the adaption of the folic acid contents in the BLS for the calculations as well as Sabine Kulling and Lara Frommherz (Max Rubner-Institut, Dept. Safety and Quality of Fruit and Vegetables) for the analyses of folic acid in multivitamin juices. The original survey (NVS II) was funded by the German Federal Ministry of Food, Agriculture and Consumer Protection (BMELV).

Conflict of interest On behalf of all authors, the corresponding author states that there is no conflict of interest.

Open Access This article is distributed under the terms of the Creative Commons Attribution License which permits any use, distribution, and reproduction in any medium, provided the original author(s) and the source are credited.

\section{References}

1. Scholl TO, Johnson WG (2000) Folic acid: influence on the outcome of pregnancy. Am J Clin Nutr 71:1295S-1303S

2. Wald NJ (1991) Prevention of neural tube defects: results of the Medical Research Council Vitamin Study. Lancet 338:131-137. doi:10.1016/0140-6736(91)90133-A

3. Czeizel AE (1995) Nutritional supplementation and prevention of congenital abnormalities. Curr Opin Obstet Gynecol 7:88-94. doi:10.1097/00001703-199504000-00003

4. Blom HJ, Smulders Y (2011) Overview of homocysteine and folate metabolism. With special references to cardiovascular disease and neural tube defects. J Inherit Metab Dis 34:75-81. doi:10.1007/s10545-010-9177-4

5. Duthie SJ (2011) Folate and cancer: how DNA damage, repair and methylation impact on colon carcinogenesis. J Inherit Metab Dis 34:101-109. doi:10.1007/s10545-010-9128-0

6. Liu S, Manson JE, Lee IM, Cole SR, Hennekens CH, Willett WC, Buring JE (2000) Fruit and vegetable intake and risk of cardiovascular disease: the Women's Health Study. Am J Clin Nutr 72:922-928

7. Chen J, Xu X, Liu A, Ulrich CM (2010) Folate and cancer: epidemiological perspective. In: Bailey LB (ed) Folate in health and disease, 2nd edn. CRC Press, Boca Raton, pp 205-233

8. Liu SM, Stampfer MJ, Hu FB, Giovannucci E, Rimm E, Manson JE, Hennekens CH, Willett WC (1999) Whole-grain consumption and risk of coronary heart disease: results from the Nurses' Health Study. Am J Clin Nutr 70:412-419

9. Clarke R, Halsey J, Bennett D, Lewington S (2011) Homocysteine and vascular disease: review of published results of the homocysteine-lowering trials. J Inherit Metab Dis 34:83-91. doi:10.1007/s10545-010-9235-y

10. Bazzano LA, Reynolds K, Holder KN, He J (2006) Effect of folic acid supplementation on risk of cardiovascular diseases-a metaanalysis of randomized controlled trials. JAMA 296:2720-2726. doi:10.1001/jama.296.22.2720

11. Wang XB, Qin XH, Demirtas H, Li JP, Mao GY, Huo Y, Sun NL, Liu LH, Xu XP (2007) Efficacy of folic acid supplementation in stroke prevention: a meta-analysis. Lancet 369:1876-1882. doi:10.1016/S0140-6736(07)60854-X

12. McMahon JA, Green TJ, Skeaff CM, Knight RG, Mann JI, Williams SM (2006) A controlled trial of homocysteine lowering and cognitive performance. N Engl J Med 354:2764-2772. doi:10.1056/NEJMoa054025

13. Durga J, van Boxtel MP, Schouten EG, Kok FJ, Jolles J, Katan MB, Verhoef P (2007) Effect of 3-year folic acid supplementation on cognitive function in older adults in the FACIT trial: a randomised, double blind, controlled trial. Lancet 369:208-216. doi:10.1016/S0140-6736(07)60109-3

14. Figueiredo JC, Grau MV, Haile RW, Sandler RS, Summers RW, Bresalier RS, Burke CA, McKeown-Eyssen GE, Baron JA (2009) Folic acid and risk of prostate cancer: results from a randomized clinical trial. J Natl Cancer Inst 101:432-435. doi:10.1093/jnci/ djp019

15. Smith AD, Kim YI, Refsum H (2008) Is folic acid good for everyone? Am J Clin Nutr 87:517-533

16. Kim YI (2007) Folate and colorectal cancer: an evidence-based critical review. Mol Nutr Food Res 51:267-292. doi:10.1002/ mnfr.200600191

17. Ebbing M, Bonaa KH, Nygard O, Arnesen E, Ueland PM, Nordrehaug JE, Rasmussen K, Njolstad I, Refsum H, Nilsen DW, Tverdal A, Meyer K, Vollset SE (2009) Cancer incidence and mortality after treatment with folic acid and vitamin B12. JAMA 302:2119-2126. doi:10.1001/jama.2009.1622

18. Kim YI (2008) Folic acid supplementation and cancer risk: point. Cancer Epidemiol Biomark Prev 17:2220-2225. doi:10.1158/ 1055-9965.epi-07-2557

19. Stolzenberg-Solomon RZ, Chang SC, Leitzmann MF, Johnson KA, Johnson C, Buys SS, Hoover RN, Ziegler RG (2006) Folate intake, alcohol use, and postmenopausal breast cancer risk in the prostate, lung, colorectal, and ovarian cancer screening trial. Am J Clin Nutr 83:895-904

20. Kim YI (2004) Folate, colorectal carcinogenesis, and DNA methylation: lessons from animal studies. Environ Mol Mutagen 44:10-25. doi:10.1002/em.20025

21. Selhub J, Morris MS, Jacques PF, Rosenberg IH (2009) Folatevitamin B-12 interaction in relation to cognitive impairment, anemia, and biochemical indicators of vitamin B-12 deficiency. Am J Clin Nutr 89:702S-706S. doi:10.3945/ajen.2008.26947C

22. Selhub J, Morris MS, Jacques PF (2007) In vitamin B12 deficiency, higher serum folate is associated with increased total homocysteine and methylmalonic acid concentrations. Proc Natl Acad Sci USA 104:19995-20000. doi:10.1073/pnas.0709487104

23. Morris MS, Jacques PF, Rosenberg IH, Selhub J (2007) Folate and vitamin B 12 status in relation to anemia, macrocytosis, and cognitive impairment in older Americans in the age of folic acid fortification. Am J Clin Nutr 85:193-200

24. Salim A, Tan E, Ilchyshyn A, Berth-Jones J (2006) Folic acid supplementation during treatment of psoriasis with methotrexate: a randomized, double-blind, placebo-controlled trial. Br J Dermatol 154:1169-1174. doi:10.1111/j.1365-2133.2006.07289.x

25. Carter JY, Loolpapit MP, Lema OE, Tome JL, Nagelkerke NJD, Watkins WM (2005) Reduction of the efficacy of antifolate antimalarial therapy by folic acid supplementation. Am J Trop Med Hyg 73:166-170

26. Khanna D, Park GS, Paulus HE, Simpson KM, Elashoff D, Cohen SB, Emery P, Dorrier C, Furst DE (2005) Reduction of the efficacy of methotrexate by the use of folic acid-post hoc analysis from two randomized controlled studies. Arthritis Rheum 52:3030-3038. doi:10.1002/art.21295

27. European Food Safety Authority (2009) ESCO report prepared by the EFSA scientific cooperation working group on analysis of risks and benefits of fortification of food with folic acid. http://www.efsa.europa.eu/en/scdocs/doc/3e.pdf. Accessed 27 May 2014

28. Deutsche Gesellschaft für Ernährung, Österreichische Gesellschaft für Ernährung, Schweizerische Gesellschaft für Ernährungsforschung, Schweizerische Vereinigung für Ernährung 
(eds) (2013) Referenzwerte für die Nährstoffzufuhr (Reference Values for Nutrient Intake). Neuer Umschau Buchverlag, Neustadt an der Weinstraße

29. Max Rubner-Institut (2008) Nationale Verzehrsstudie II. Ergebnisbericht, Teil 1 (National Nutrition Survey II. First report). http://www.mri.bund.de/fileadmin/Institute/EV/NVS_II_ Abschlussbericht_Teil_1_mit_Ergaenzungsbericht.pdf. Accessed 27 May 2014

30. Slimani N, Deharveng G, Charrondière RU, van Kappel AL, Ocké MC, Welch A, Lagiou A, van Liere M, Agudo A, Pala V, Brandstetter B, Andren C, Stripp C, van Staveren WA, Riboli E (1999) Structure of the standardized computerized 24-h diet recall interview used as reference method in the 22 centers participating in the EPIC project. Comput Methods Programs Biomed 58:251-266. doi:10.1016/S0169-2607(98)00088-1

31. Krems C, Bauch A, Götz A, Heuer T, Hild A, Möseneder J, Brombach C (2006) Methoden der Nationalen Verzehrsstudie II (Methods of the National Nutrition Survey II). Ern Umschau 53:44-50

32. Max Rubner-Institut (2010) Bundeslebensmittelschlüssel (BLS): Version 3.01 (German Nutrient Database: version 3.01). http:// www.blsdb.de. Accessed 27 May 2014

33. European Union (2006) Regulation (EC) No 1925/2006 of the European Parliament and of the Council on the addition of vitamins and minerals and of certain other substances to foods. Off J Eur Union L 404:26-38

34. European Union (2009) Commission regulation (EC) No 1170/2009 amending Directive 2002/46/EC of the European Parliament and of Council and Regulation (EC) No 1925/2006 of the European Parliament and of the Council as regards the lists of vitamin and minerals and their forms that can be added to foods, including food supplements. Off J Eur Union L 314:36-42

35. The Nordic Council (2004) Nordic nutrition recommendations 2004: integrating nutrition and physical activity. Rep. No. 92-893-1062-6. Norden, Copenhagen

36. Commission of the European Communities (1993) Nutrient and energy intakes for the European Community. http://ec.europa.eu/ food/fs/sc/scf/out89.pdf. Accessed 27 May 2014

37. Department of Health (2008) Dietary reference values of food energy and nutrients for the United Kingdom: report of the panel on dietary reference values of the committee on medical aspects of food policy. Reports on health and social subjects 41. HMSO, London

38. Institute of Medicine (2000) Dietary reference intakes for thiamin, riboflavin, niacin, vitamin B6, folate, vitamin B12, pantothenic acid, biotin, and choline. National Academy Press, Washington, DC

39. European Food Safety Authority (2006) Tolerable upper intake levels for vitamins and minerals. http://www.efsa.europa.eu/en/ ndatopics/docs/ndatolerableuil.pdf. Accessed 27 May 2014

40. Frommherz L, Martiniak Y, Heuer T, Roth A, Kulling SE, Hoffmann I (2014) Degradation of folic acid in fortified vitamin juices during long term storage. Food Chem 159:122-127. doi:10. 1016/j.foodchem.2014.02.156

41. Beitz R, Mensink GBM, Fischer B, Thamm M (2002) Vitaminsdietary intake and intake from dietary supplements in Germany. Eur J Clin Nutr 56:539-545. doi:10.1038/sj.ejen.1601346

42. Thamm M, Mensink GBM, Thierfelder W (1999) Folsäureversorgung von Frauen im gebärfähigen Alter (Folate supply of women in childbearing age). Gesundheitswesen 61:S207S212

43. Elmadfa I (ed) (2009) European nutrition and health report 2009. Karger, Basel

44. Park JY, Nicolas G, Freisling H, Biessy C, Scalbert A, Romieu I, Chajes V, Chuang SC, Ericson U, Wallstrom P, Ros MM, Peeters PH, Mattiello A, Palli D, Maria Huerta J, Amiano P, Halkjaer J,
Dahm CC, Trichopoulou A, Orfanos P, Teucher B, Feller S, Skeie G, Engeset D, Boutron-Ruault MC, Clavel-Chapelon F, Crowe F, Khaw KT, Vineis P, Slimani N (2012) Comparison of standardised dietary folate intake across ten countries participating in the European Prospective Investigation into Cancer and Nutrition. Br J Nutr 108:552-569. doi:10.1017/S000711451100 5733

45. van Rossum CTM, Fransen HP, Verkaik-Kloosterman J, BuurmaRethans EJM, Ocké MC (2011) Dutch National Food Consumption Survey 2007-2010: Diet of children and adults aged 7 to 69 years. National Institute for Public Health and the Environment, Bilthoven. http://www.rivm.nl/dsresource?objectid= rivmp:55436\&type $=$ org \&disposition $=$ inline. Accessed 27 May 2014

46. Krems C, Walter C, Heuer T, Hoffmann I (2012) Lebensmittelverzehr und Nährstoffzufuhr-Ergebnisse der Nationalen Verzehrsstudie II (Food consumption and nutrient intakeresults of the German National Nutrition Survey II). In: Deutsche Gesellschaft für Ernährung (ed) Ernährungsbericht 2012, DGE, Bonn, pp 40-85

47. Kim YI (2004) Will mandatory folic acid fortification prevent or promote cancer? Am J Clin Nutr 80:1123-1128

48. Kim YI (2006) Folate: a magic bullet or a double edged sword for colorectal cancer prevention? Gut 55:1387-1389. doi:10.1136/ gut.2006.095463

49. Kim YI (2007) Folic acid fortification and supplementationgood for some but not so good for others. Nutr Rev 65:504-511. doi:10.1301/nr.2007.nov.504-511

50. Kim YI (2009) Role of the MTHFR polymorphisms in cancer risk modification and treatment. Future Oncol 5:523-542. doi:10. 2217/fon.09.26

51. Lebensmittelchemische Gesellschaft (2009) Positionspapier: Empfehlungen zu Toleranzen für die Nährstoffschwankungen bei der Nährwertkennzeichnung (Recommendations to tolerance limits for the nutrient declaration). Lebensmittelchemie 63:98-99

52. Institute of Environmental Science and Research Limited (2006) Fortification overages of the food supply, folate and iron. http:// www.foodsafety.govt.nz/elibrary/industry/Fortification_OveragesMeasuring_Actual.pdf. Accessed 27 May 2014

53. Whittaker P, Tufaro PR, Rader JI (2001) Iron and folate in fortified cereals. J Am Coll Nutr 20:247-254. doi:10.1080/ 07315724.2001.10719039

54. Black AE, Cole TJ (2001) Biased over- or under-reporting is characteristic of individuals whether over time or by different assessment methods. J Am Diet Assoc 101:70-80. doi:10.1016/ s0002-8223(01)00018-9

55. Goldberg GR, Black AE, Jebb SA, Cole TJ, Murgatroyd PR, Coward WA, Prentice AM (1991) Critical evaluation of energy intake data using fundamental principles of energy physiology: 1 . Derivation of cut-off limits to identify under-recording. Eur J Clin Nutr 45:569-581

56. Black AE (2000) Critical evaluation of energy intake using the Goldberg cut-off for energy intake:basal metabolic rate. A practical guide to its calculation, use and limitations. Int J Obes Relat Metab Disord 24:1119-1130. doi:10.1038/sj.ijo.0801376

57. Müller MJ, Bosy-Westphal A, Klaus S, Kreymann G, Lührmann PM, Neuhäuser-Berthold M, Noack R, Pirke KM, Platte P, Selberg O, Steiniger J (2004) World Health Organization equations have shortcomings for predicting resting energy expenditure in persons from a modern, affluent population: generation of a new reference standard from a retrospective analysis of a German database of resting energy expenditure. Am J Clin Nutr 80:1379-1390

58. Tooze JA, Kipnis V, Buckman DW, Carroll RJ, Freedman LS, Guenther PM, Krebs-Smith SM, Subar AF, Dodd KW (2010) A mixed-effects model approach for estimating the distribution of 
usual intake of nutrients: the NCI method. Stat Med 29:2857-2868. doi:10.1002/sim.4063

59. Harttig U, Haubrock J, Knüppel S, Boeing H (2011) The MSM program: web-based statistics package for estimating usual dietary intake using the multiple source method. Eur J Clin Nutr 65(Suppl 1):S87-S91. doi:10.1038/ejen.2011.92
60. Lucock M, Yates Z, Boyd L, Naylor C, Choi JH, Ng X, Skinner V, Wai R, Kho J, Tang S, Roach P, Veysey M (2013) Vitamin $\mathrm{C}$-related nutrient-nutrient and nutrient-gene interactions that modify folate status. Eur J Nutr 52:569-582. doi:10.1007/s00394012-0359-8 